\title{
COMPARATIVE STUDY OF ALCOHOLIC AND AQUEOUS EXTRACTS OF SYZYGIUM CUMINI ON CARBON TETRACHLORIDE-INDUCED HEPATOTOXICITY IN WISTAR RATS
}

\author{
SHWETA SHARMA*, MEHTA BK \\ Department of Chemistry and Biochemistry, School of Studies, Vikram University, Ujjain - 456 010, Madhya Pradesh, India. \\ Email: sharma.harshali10@gmail.com
}

Received: 12 August 2016, Revised and Accepted: 17 August 2016

\section{ABSTRACT}

Objective: In this investigation, the comparative hepatoprotective effect of aqueous and ethanolic extracts of Syzygium cumini (AESC and EESC, respectively) was studied on carbon tetrachloride $\left(\mathrm{CCl}_{4}\right)$-induced hepatic injury in rats. These findings were also compared with the standard hepatoprotective drug silymarin.

Methods: Hepatotoxicity was induced by a single dose of $\mathrm{CCl}_{4}$ to healthy Wistar rats. Standard drug $(100 \mathrm{mg} / \mathrm{kg})$ and test extracts $(500 \mathrm{mg} / \mathrm{kg}$ for both) were given orally for 10 days; the effects were observed using different biochemical and histological methods.

Results: In most of the studied parameters test extracts exhibited significant hepatoprotection, these were comparative to standard. Histological analysis also revealed the protective nature of both the extracts.

Conclusion: These results suggest that the $\mathrm{SC}$ extracts can ameliorate $\mathrm{CCl}_{4}$ induced hepatic injury. However, its ethanolic extract was found to be relatively less effective than aqueous extract. Indicated, some hydrophilic active compound of SC might work here.

Keywords: Hepatoprotective, Carbon tetrachloride, Silymarin, Syzygium cumini, Alkaline phosphatase, Total bilirubin.

(C) 2016 The Authors. Published by Innovare Academic Sciences Pvt Ltd. This is an open access article under the CC BY license (http://creativecommons. org/licenses/by/4. 0/) DOI: http://dx.doi.org/10.22159/ajpcr.2016.v9s3.14675

\section{INTRODUCTION}

The liver is the principle organ which maintain body's internal environment and control the metabolism of carbohydrate, protein, and fats [1]. It is also the primary site of almost all the biochemical pathways to growth, fight against disease, nutrient supply and storage, energy provision, detoxification, and reproduction [2,3]. Thus, to maintain a healthy liver is an essential factor for the overall health and well-being [4]

Hepatotoxicity means chemical-driven liver damage since liver cells are main site of detoxification and drug metabolism, certain toxin/ drug might injure the organ [3-5]. In addition, exposure of chemical agents which are used in laboratories and industries can also induce hepatotoxicity [6]. The previous investigations revealed that nearly 40,000 deaths per year happened due different liver diseases [7].

The root cause of any chemical-induced toxicity is the generation of free radicals [4]. Carbon tetrachloride $\left(\mathrm{CCl}_{4}\right)$ is a known pro-oxidative compound which has been extensively used to study liver injury induced by reactive oxygen species (ROS). The hepatotoxic effect of $\mathrm{CCl}_{4}$ is considered to be initiated as a result of its reductive dehalogenation by cytochrome $\mathrm{P} 4502 \mathrm{E} 1$, this produce highly reactive trichloromethyl radical $\left(+\mathrm{CCl}_{3}\right)$, in the presence of oxygen $+\mathrm{CCl}_{3}$ further converted into a trichloromethyl peroxyl radical $\left(+\mathrm{OOCCl}_{3}\right)$ [8]. These free radicals are highly reactive and may cause damages to tissue lipids and proteins $[4,9]$. In a number of reports, these free radicals have been reported to induce membrane lipid peroxidation and protein oxidation [7-9]. The more deleterious effects are on enzymatic system of the cells [9]. Activities of liver function enzymes such as alkaline phosphatase (ALP), serum glutamic oxaloacetic transaminase (SGOT), and serum glutamic pyruvic transaminase (SGPT) are also disturbed. These are well-recognized markers of tissue cirrhosis, necrosis, decreased functioning and abnormal metabolism, etc. [10,11].

Antioxidants are well-known protective agents which either inhibit generation of free radicals or by enhance their removal $[7,9]$. Thousands of herbs have been reported to have antioxidative property [6,10-12]
Although several allopathic drugs are available, number of reports also stated their detrimental side effects on body's functioning [13]. Therefore, plant-based therapy is supposed to be more reliable [10]. Plant parts and their extracts are potential agents for the management and treatment of oxidative stress-induced diseases [11,13]. Because these medicines are not only economic and affordable but are also safer and are extensively using as effective medication [14]. The Syzygium cumini (SC) is a popular traditional medicinal plant, which exhibits tremendous pharmacological effect in different experimental works. For example, its stem bark is a rich source of eugenin, quercetin, kaempferol, bergenins, flavianoids, tannins, pentacyclic triterpenoid betulinic acid, ester of epifriedelanol, friedelin and $\beta$-sitosterol, etc. [15-17]. The known antioxidants such as gallic acid, ellagic acid, resin, etc. are also known to be present in the bark [18]. In different premedical and medical analysis, different parts of this plant have been known to show immunomodulatory, hypolipidemic, antidiabetic, antibacterial, and the inflammatory action $[13,15]$. However, reports on the hepatoprotective effects against oxidative injury are meagre.

As different active constituents have differential medicinal potencies so these can be extracted in different extraction medium [19]. In this investigation, the less studied hepatoprotective efficacy of ethanolic and aqueous extracts of SC (EESC and AESC) was studied in $\mathrm{CCl}_{4}$ induced hepatotoxic rats. Enzymatic activity such as ALP, SGOT, and SGPT as well as serum total bilirubin (TBil) was taken as studied parameters. Silymarin a known hepatoprotective drug $[10,19]$ also used as a standard to reveal the relative potency of the test extracts. Tissue histology was also done to confirm the results.

\section{METHODS}

\section{Chemicals}

All chemicals were of the highest commercially available purity. The bark of SC was collected from D-1 University Campus, Dewas Road, Ujjain, Madhya Pradesh, India. The identification of plant was done in Department of Botany, Safia College of Science, Bhopal (Madhya Pradesh) and the voucher specimen 438/Bot/saf/13, was deposited in the Safia College of Science, Bhopal (Madhya Pradesh). 
Preparation of extracts

To prepare the extract of SC bark, the cleaned and air-dried bark was ground to a coarse powder. The powdered bark was exhaustively extracted is in soxhlet extractor with ethanol. Removal of solvent under reduced pressure afforded solid mass. Ethanol extract was obtained in good amount. For the preparation of aqueous extract, the bark powder was oaked in distilled water in a flask for $24 \mathrm{hrs}$. After that, the solution was filtered by Whatman filter paper (no. 1) and the filtrate was collected. The residue was again soaked with 20 volume distilled water to get additional extractives. All the filtrates were collected in a round bottom flask. Gummy substance was obtained using vacuum rotary evaporator. Then, the substance was dried at room temperature. The powdered extract was stored at $40^{\circ} \mathrm{C}$ for further experiment.

\section{Animals}

Healthy inbred albino Wistar rats of either sex (2-2.5 months old) were housed in polypropylene cages under constant temperature $\left(27 \pm 2^{\circ} \mathrm{C}\right)$ and photo schedule ( $14 \mathrm{hrs}$ light and $10 \mathrm{hrs}$ dark). They were provided rodent feed (Golden Feeds, New Delhi, India) ad libitum and had free access to boiled drinking water. The approval of departmental ethical committee for handling and maintenance for experimental animals was also obtained before starting the experiments.

\section{Induction of hepatotoxicity}

Hepatic injury was induced by single oral administration of $\mathrm{CCl}_{4}$ mixed with olive oil as vehicle in $1: 1$ ratio ( $3 \mathrm{ml} / \mathrm{kg}$ of rat body weight). Animals with hepatic injury were posttreated with silymarin and extracts.

\section{Experimental design}

In the experiment, a total of 30 rats were used, which were divided into five groups having six animals in each group as follows:

- Group I: Normal control rats received $1 \mathrm{ml} / 100 \mathrm{~g}$ of $0.5 \%$ per oral for 10 days

- Group II: Negative control rats received $\mathrm{CCl}_{4} 3 \mathrm{ml} / \mathrm{kg}$, p.o. only once a day 1

- Group III: Rats received $\mathrm{CCl}_{4} 3 \mathrm{ml} / \mathrm{kg}$, p.o. and Silymarin (100 mg/kg, p.o.) for next 10 days, designated as STAND group

- Group IV: Rats received $\mathrm{CCl}_{4} 3 \mathrm{ml} / \mathrm{kg}$, p.o. and AESC (500 mg/kg p.o.) once daily for 10 days, designated as AESC group

- Group V: Rats received $\mathrm{CCl}_{4} 3 \mathrm{ml} / \mathrm{kg}$, p.o. and EESC (500 mg/kg p.o.) once daily for 10 days, designated as EESC group.

At the end of the experiment on the $10^{\text {th }}$ day, animals were kept on overnight fasting and blood was collected by orbital puncture method. This blood was then allowed to clot for 30 minutes at room temperature. The serum was separated by centrifugation at $3000 \mathrm{rpm}$ at $30^{\circ} \mathrm{C}$ for 15 minutes.

\section{Biochemical estimation}

The serum samples were analyzed spectrophotometrically for ALP, SGOT, SGPT, and TBil levels using standard kits (Span Diagnostics Ltd). The activity of SGOT and SGPT was measured at $505 \mathrm{~nm}$ and is expressed as IU/L of serum. In ALP assay, the blue color developed which was read at $510 \mathrm{~nm}$ against blank and the activity is expressed as $\mathrm{IU} / \mathrm{L}$ of serum. To estimate the TBil readings were taken at $540 \mathrm{~nm}$, the level of TBil was expressed as $\mathrm{mg} / \mathrm{dL}$ of serum [20].

\section{Histological study}

Histopathological study was done using the protocol of Deepa and Varalakshmi [21]. Tissues were fixed in 10\% formaldehyde and then dehydrated in descending grades of isopropanol, cleared in xylene, and then embedded in molten paraffin wax. These fixed tissues were subsequently cut into $5 \mu \mathrm{m}$ thick sections using microtome. The ribbons were then stained with hematoxylin and eosin and viewed under light microscope to study histopathological changes.

\section{Statistical analysis}

Data are expressed as mean \pm standard error. Statistical analysis was performed using one-way ANOVA followed by unpaired Student's t-test and $p$-values of $5 \%$ and less were considered as significant.

\section{RESULTS AND DISCUSSION}

As compared to normal control animals $\mathrm{CCl}_{4}$ induced animals showed significant increased values of serum ALP, SGOT, SGPT, and TBil ( $<<0.001$, for all), as showed in Figs. 1-4. As already demonstrated earlier, here also treatment with standard drug significantly reduced, the values of all above mentioned parameters $(\mathrm{p}<0.05, \mathrm{p}<0.001, \mathrm{p}<0.0001$, and $\mathrm{p}<0.001$, respectively). AESC administration showed significant reduction in TBil $(\mathrm{p}<0.001)$, SGOT and SGPT $(\mathrm{p}<0.001$, for both) than induced group but these values are significantly less effective than that of standard drug for SGPT $(p<0.001)$ and SGOT $(p<0.05)$. Treatment with EESC also found to be considerably effective, as it reduces the increased values of TBil $(\mathrm{p}<0.01)$, SGPT and SGOT ( $<<0.001$, for both) than induced group. Comparative analysis showed that the treatment with EESC was found to less effective ( $p<0.05$ or more) or ineffective than standard drug and AESC for some of the parameters. Histological analysis also revealed that the both the extracts showed less or more hepatoprotective activities (Fig. 5).

In this experiment, we found that the AESC has more hepatoprotective activity than EESC. In addition, their protective efficacy was also found to be comparable to that of standard drug used. Induction of oxidative

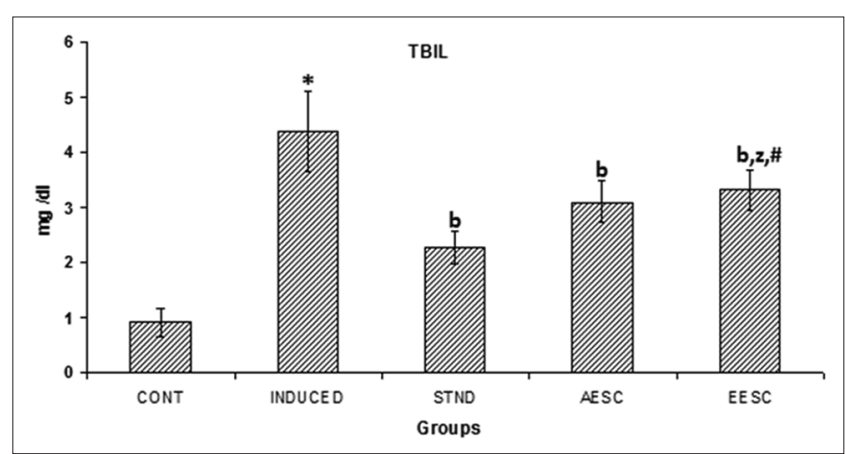

Fig. 1: Effects of different extracts of Syzygium cumini (SC) on serum total bilirubin (TBIL) in experimental animals. Cont (Normal control), induced (carbon tetrachloride $\left[\mathrm{CCl}_{4}\right]$ treated), STAND ( $\mathrm{CCl}_{4}+$ silymarin), aqueous extracts of SC (AESC) $\left(\mathrm{CCl}_{4}+\mathrm{AESC}\right)$, and ethanolic extracts of SC (EESC) $\left(\mathrm{CCl}_{4}+\mathrm{EESC}\right)$. Each bar represents, the mean \pm standard error $(n=6),{ }^{*} p<0.001$, as compared to normal control, ${ }^{\mathrm{a}} \mathrm{p}<0.05$ and ${ }^{\mathrm{b}} \mathrm{p}<0.01$ as compared to $\mathrm{CCl}_{4}$ treated group, and ${ }^{\mathrm{x}} \mathrm{p}<0.05,{ }^{\mathrm{y}} \mathbf{p}<0.01$, and ${ }^{\mathrm{z}} \mathrm{p}<0.001$ as compared to standard drug, whereas ${ }^{\#} p<0.05$ than AESC group

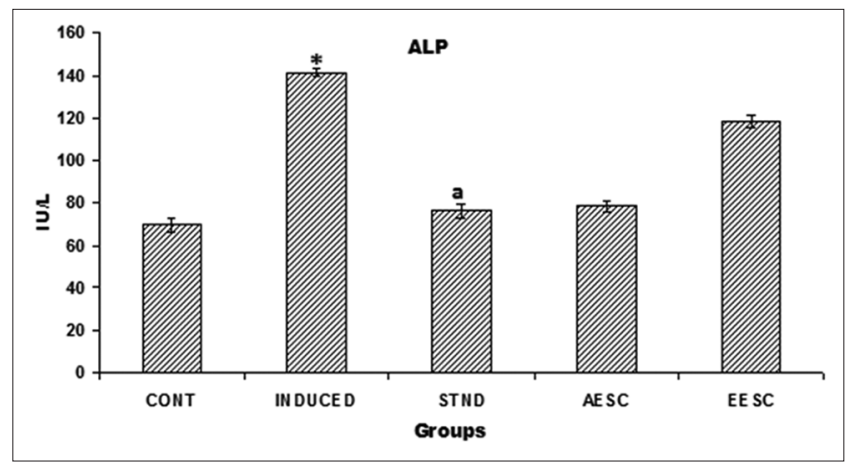

Fig. 2: Effects of different extracts of Syzygium cumini (SC) on alkaline phosphatise (ALP) in experimental animals. Cont (Normal control), Induced (carbon tetrachloride $\left[\mathrm{CCl}_{4}\right]$ treated), STAND $\left(\mathrm{CCl}_{4}+\right.$ silymarin $)$, aqueous extract of $\mathrm{SC}\left(\mathrm{CCl}_{4}+\mathrm{AESC}\right)$, and ethanolic extract of $\mathrm{SC}\left(\mathrm{CCl}_{4}+\mathrm{EESC}\right)$. Each bar represents, the mean \pm standard error $(n=6),{ }^{*} \mathbf{p}<0.001$, as compared to normal control, ${ }^{a} p<0.05$ and ${ }^{b} p<0.01$ as compared to $\mathrm{CCl}_{4}$ treated group, and ${ }^{x} \mathbf{p}<0.05,{ }^{y} p<0.01$ and ${ }^{z} p<0.001$ as compared to standard drug, whereas $" p<0.05$ than AESC group 


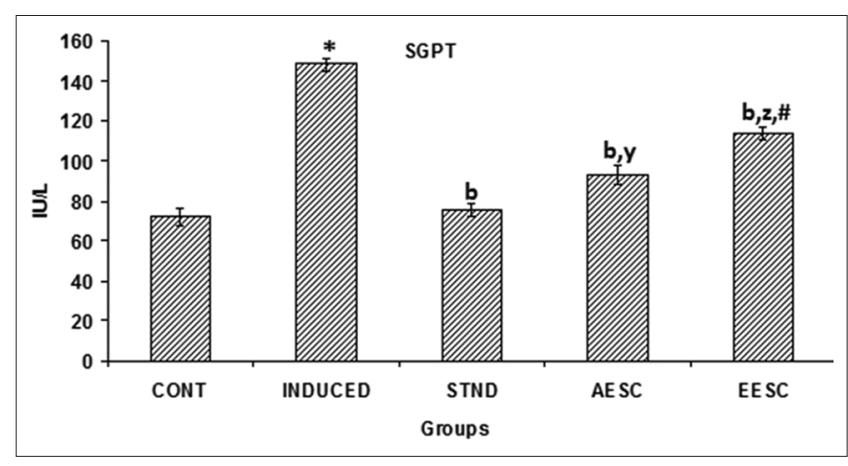

Fig. 3: Effects of different extracts of Syzygium cumini (SC) on serum glutamic pyruvic transaminase (SGPT) in experimental animals. Cont (Normal control), Induced (carbon tetrachloride $\left[\mathrm{CCl}_{4}\right]$ treated), STAND $\left(\mathrm{CCl}_{4}+\right.$ silymarin), aqueous extract of $\mathrm{SC}\left(\mathrm{CCl}_{4}+\mathrm{AESC}\right)$, ethanolic extract of $\mathrm{SC}\left(\mathrm{CCl}_{4}+\mathrm{EESC}\right)$. Each bar represents, the mean \pm standard error $(n=6), * p<0.001$ as compared to normal control, ${ }^{\mathrm{a}} \mathrm{p}<0.05$ and ${ }^{\mathrm{b}} \mathrm{p}<0.01$ as compared to carbon tetrachloride treated group, and ${ }^{\mathrm{x}} \mathrm{p}<0.05,{ }^{\mathrm{y}} \mathrm{p}<0.01$, and ${ }^{z} p<0.001$ as compared to standard drug, whereas ${ }^{\#} p<0.05$ than AESC group

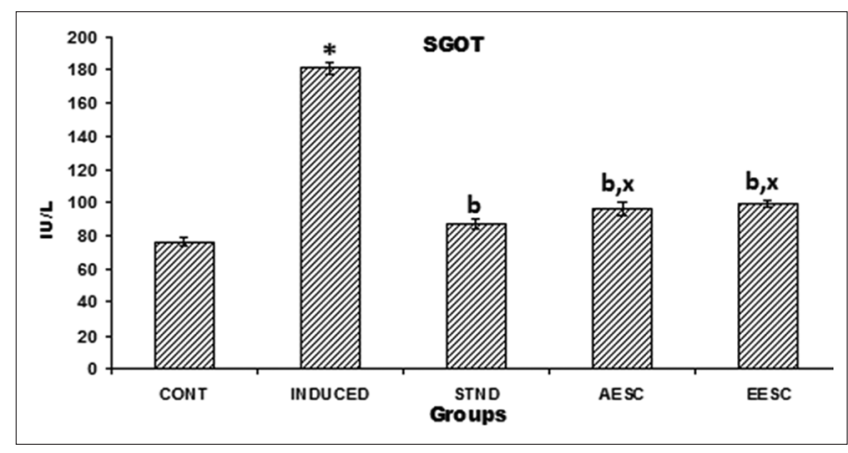

Fig. 4: Effects of different extracts of Syzygium cumini (SC) on serum glutamic oxaloacetic transaminase (SGOT) in experimental animals. Cont (Normal control), Induced (carbon tetrachloride $\left[\mathrm{CCl}_{4}\right]$ treated), STAND $\left(\mathrm{CCl}_{4}+\right.$ silymarin), aqueous extract of $\mathrm{SC}\left(\mathrm{CCl}_{4}+\mathrm{AESC}\right)$, ethanolic extract of $\mathrm{SC}\left(\mathrm{CCl}_{4}+\mathrm{EESC}\right)$. Each bar represents, the mean \pm standard error $(n=6),{ }^{*} p<0.001$, as compared to normal control, ${ }^{\mathrm{a}} \mathrm{p}<0.05$ and ${ }^{\mathrm{b}} \mathrm{p}<0.01$ as compared to $\mathrm{CCl}_{4}$ treated group, and ${ }^{\mathrm{x}} \mathrm{p}<0.05,{ }^{\mathrm{y}} \mathrm{p}<0.01$, and ${ }^{\mathrm{z}} \mathrm{p}<0.001$ as compared to standard drug, whereas $\#<0.05$ than AESC group

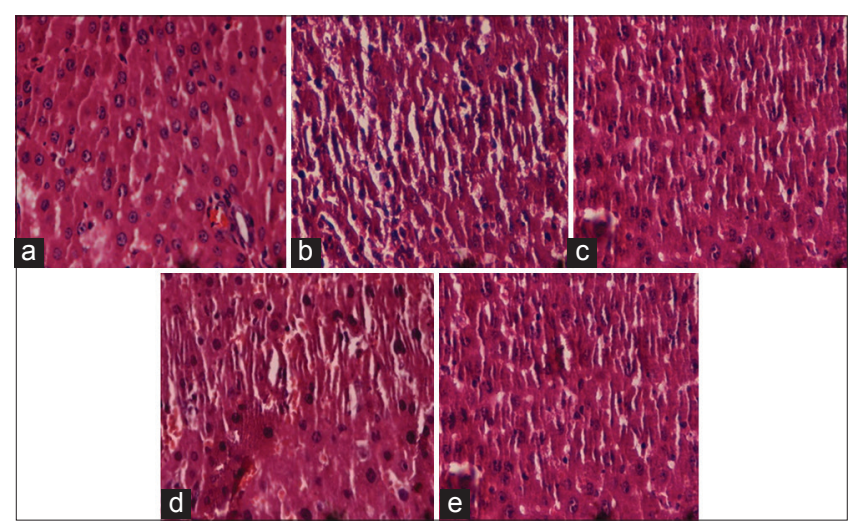

Fig. 5: Histology of different experimental animals. (a) Normal control, (b) induced (carbon tetrachloride $\left[\mathrm{CCl}_{4}\right]$ treated), (c) STAND ( $\mathrm{CCl}_{4}+$ silymarin), (d) aqueous extract of Syzygium cumini (SC) (AESC) $\left(\mathrm{CCl}_{4}+\mathrm{AESC}\right)$, and (e) ethanolic extract of SC $\left(\mathrm{CCl}_{4}+\mathrm{EESC}\right)$ injury with the $\mathrm{CCl}_{4}$ treatment has already been reported earlier $[6,8,9]$. This is a characteristic system of the xenobiotic-induced hepatotoxicity and is a commonly used model for the screening of hepatoprotective activity $[10,11]$.

Generation of excessive ROS may result in damaged plasma membrane, which unable the plasma membrane to resist the leakage of cytosolic proteins into the bloodstream $[18,21]$. Hence, their increased serum values are used as a useful quantitative marker of the extent and type of hepatocellular damage. The increased levels of SGOT, SGPT ALP, and TBil in $\mathrm{CCl}_{4}$ induced rats interpreted as a result of the liver cell destruction or changes in the membrane permeability indicated severity of hepatocellular damage by $\mathrm{CCl}_{4}[8,10]$.

TBil measurement includes both unconjugated and conjugated bilirubin. Unconjugated bilirubin is a breakdown product of heme is mainly transported bound to albumin circulating in the blood [22]. The addition of high concentration hydrophobic drugs, chemicals, and high free fatty acids can cause elevated unconjugated bilirubin [23]. The liver is responsible for clearing the blood of unconjugated bilirubin by uridine 5 '-diphospho-glucuronyl-transferase, and secreted into the bile by canalicular multispecific organic anion transporter 1 (multidrug resistance-associated protein 2); these are usually excreted into the intestine. However, in the case of hepatobiliary disease and severe disturbance of hepatocellular function, TBil level enchases [22,23]. The extracts mediated suppression of the increased bilirubin level caused by $\mathrm{CCl}_{4}$ suggests the possibility of the extracts being able to stabilize biliary dysfunction.

ALP is an active enzyme in the cells lining the biliary ducts of the liver and it's increased level indicates large bile duct obstruction, intrahepatic cholestasis, or infiltrative diseases of the liver [13,17]. However, it's elevated values in growing children and in the third trimester of pregnancy is normal. In this investigation, the SC extracts were seemed to be non-significantly effective for the activity of ALP. This might indicate that both AESC and EESC served via different mechanism [24]

Moreover, biliary tract disease produces relatively greater increases in ALP than increases in SGOT and SGPT. These two are another set of enzymes associated with liver parenchymal cells [22] and are elevated in acute liver damage, but is also present in red blood cells, and cardiac and skeletal muscle, so is not specific to the liver [25]. The rise in SGOT activity is almost due to hepatocellular damage and is usually accompanied by the rise in SGPT [22,23]. Here, treatment with the different extracts attenuated the increased activities of these enzymes in serum. Recovery toward the normalization suggests that these extracts caused parenchymal cell regeneration in liver, thus protecting membrane fragility and thereby decreasing enzyme leakage [25].

\section{CONCLUSION}

The present finding revealed that $\mathrm{CCl}_{4}$ induced hepatotoxic model indicated drastic elevated values of liver stress markers, which were observed to be recovered in both test extracts. In addition to this, probably hydrophilic ingredients of the SC were seemed to more protective than hydrophobic compound rich extracts. Since the effects were extract specific and also depend on the stress parameters used, so to know the exact mechanism of protective action of the used extracts further studied are needed.

\section{REFERENCES}

1. Hensley K, Robinson KA, Gabbita SP, Salsman S, Floyd RA. Reactive oxygen species, cell signaling, and cell injury. Free Radic Biol Med 2000;28(10):1456-62.

2. Vadivu R, Vidhya S, Jayshree N. Standardization and evaluation of hepatoprotective activity of polyherbal capsule. Int J Pharm Sci Rev Res 2013;21(1):93-9.

3. Halim AB, el-Ahmady O, Hassab-Allah S, Abdel-Galil F, Hafez Y, Darwish A. Biochemical effect of antioxidants on lipids and liver 
function in experimentally-induced liver damage. Ann Clin Biochem 1997;34:656-63.

4. Pari L, Latha M. Antidiabetic effect of Scoparia dulcis: Effect on lipid peroxidation in streptozotocin diabetes. Gen Physiol Biophys 2005;24(1):13-26

5. Ronsein GE, Guidi DB, Benassi JC, Filho DW, Pedrosa RC, Pedrosa RC. Cytoprotective effects of carvedilol against oxygen free radical generation in rat liver. Redox Rep 2005;10(3):131-7.

6. Pandit A, Sachdeva T, Bafna P. Drug-induced hepatotoxicity: A review. J Appl Pharm Sci 2012;2(5):233-43.

7. Bénichou C. Criteria of drug-induced liver disorders. Report of an international consensus meeting. J Hepatol 1990;11(2):272-6.

8. Recknagel RO, Glende EA Jr, Dolak JA, Waller RL. Mechanisms of carbon tetrachloride toxicity. Pharmacol Ther 1989;43(1):139-54.

9. Jyoti A, Anand K, Sunanda P. Synergistic action of phytochemicals augments their antioxidative efficacy: An in vitro comparative study. Asian J Pharm Clin Res 2013;6 Suppl 4:121-6.

10. Chatterjee K, Ali KM, De D, Panda DK, Ghosh D. Antidiabetic and antioxidative activity of ethyl acetate fraction of hydromethanolic extract of seed of Eugenia jambolana Linn through in-vivo and in-vitro study and its chromatographic purification. Free Radic Antioxid 2012;2:21-30.

11. Maritim AC, Sanders RA, Watkins JB $3^{\text {rd }}$. Diabetes, oxidative stress, and antioxidants: A review. J Biochem Mol Toxicol 2003;17(1):24-38.

12. Cohen PA, Ernst E. Safety of herbal supplements: A guide for cardiologists. Cardiovasc Ther 2010;28(4):246-53.

13. Chan E, Tan M, Xin J, Sudarsanam S, Johnson DE. Interactions between traditional Chinese medicines and Western therapeutics. Curr Opin Drug Discov Devel 2010;13(1):50-65.

14. Agrawal J, Kar A. Concentration dependent anti-oxidative \& prooxidative effects of Madhumehari in in vitro and in alloxan induced diabetic mice model. Int J Pharm Sci Rev Res 2013;23(2):185-90.

15. Banerjee A, Dasgupta N, De B. In vitro study of antioxidant activity of
Syzygium cumini fruit. Food Chem 2005;90(4):727-33.

16. Benherlal PS, Arumughan C. Chemical composition and in vitro antioxidant studies on Syzygium cumini fruit. J Sci Food Agric 2007;87(14):2560-9.

17. Jagetia GC, Baliga MS. Syzygium cumini (Jamun) reduces the radiation-induced DNA damage in the cultured human peripheral blood lymphocytes: A preliminary study. Toxicol Lett 2002;132(1):19-25.

18. Ayyanar M, Subash-Babu P. Syzygium cumini (L.) Skeels: A review of its phytochemical constituents and traditional uses. Asian Pac J Trop Biomed 2012;2(3):240-6.

19. Ramachandra Setty S, Quereshi AA, Viswanath Swamy AH, Patil T, Prakash T, Prabhu K, et al. Hepatoprotective activity of Calotropis procera flowers against paracetamol-induced hepatic injury in rats. Fitoterapia 2007;78(7-8):451-4.

20. Achliya GS, Wadodkar SG, Dorle AK. Evaluation of hepatoprotective effect of Amalkadi Ghrita against carbon tetrachloride-induced hepatic damage in rats. J Ethnopharmacol 2004;90(2-3):229-32.

21. Deepa PR, Varalakshmi P. Protective effects of certoparin sodium, a low molecular weight heparin derivative, in experimental atherosclerosis. Clin Chim Acta 2004;339(1-2):105-15.

22. Gunturu KS, Nagarajan P, McPhedran P, Goodman TR, Hodsdon ME, Strout MP. Ayurvedic herbal medicine and lead poisoning. J Hematol Oncol 2011;4:51.

23. Ernst E. How the public is being misled about complementary/ alternative medicine. J R Soc Med 2008;101(11):528-30.

24. O'Malley SS, Gueorguieva R, Wu R, Jatlow PI. Acute alcohol consumption elevates serum bilirubin: An endogenous antioxidant. Drug Alcohol Depend 2015;149:87-92.

25. Vera T, D'Agostino RB Jr, Jordan JH, Whitlock MC, Meléndez GC, Lamar ZS, et al. Relation of pre-anthracycline serum bilirubin levels to left ventricular ejection fraction after chemotherapy. Am J Cardiol 2015;116(11):1752-5. 